\title{
Saint-Lô - Rue du Buot
}

$n^{\circ} 3481$

Ludovic Le Gaillard

\section{(2) OpenEdition}

Édition électronique

URL : http://journals.openedition.org/adlfi/16782

ISSN : 2114-0502

Éditeur

Ministère de la culture

Référence électronique

Ludovic Le Gaillard, «Saint-Lô - Rue du Buot », ADLFI. Archéologie de la France - Informations [En ligne], Basse-Normandie, mis en ligne le 26 février 2016, consulté le 01 mai 2019. URL : http:// journals.openedition.org/adlfi/16782

Ce document a été généré automatiquement le 1 mai 2019.

(C) Ministère de la Culture et de la Communication, CNRS 


\title{
Saint-Lô - Rue du Buot
}

\author{
$n^{\circ} 3481$
}

\author{
Ludovic Le Gaillard
}

Lien Atlas (MCC) :

http://atlas.patrimoines.culture.fr/atlas/trunk/index.php?

ap_theme=DOM_2.01.02\&ap_bbox=-1.127;49.085;-1.036;49.139

1 La viabilisation à venir de cinq prés au sud de Saint-Lô, à moins d'un kilomètre de la ville médiévale, a fait ressortir une extraction de limon et de schiste qui pourrait dater du XII ou du XIII ${ }^{\mathrm{e}}$ s. Toutefois, cette datation repose sur fort peu de tessons et doit être regardée comme une hypothèse.

2 Les vestiges concernés tiennent en deux zones de stratigraphie perturbée, au fond desquelles apparaissent les fosses d'extraction. On observe en profondeur, au contact du substrat, une couche de limon organique, puis des excavations de tailles et de plans divers; l'ensemble évoque un cumul de décapages et d'extractions, mais il n'est pas stratifié.

3 Dans les cinq hectares concernés, la majeure partie des structures découvertes tiennent toutefois en fossés, qu'il faut sans doute voir comme des limites agraires fossiles. Celles-ci présentent la même orientation que le parcellaire actuel mais dessinent des lanières qu'on ne voit plus aujourd'hui dans le bocage. Elles contiennent l'une des deux zones de l'extraction médiévale.

4 L'ensemble est scellé par un remblai de terre et de pierres, régulièrement épandu dans quatre des prés sur une épaisseur de $40 \mathrm{~cm}$. Limitant ce remblai vers le bas de pente, un mur ruiné sous une haie doit être compris comme un soutènement : il est très certainement moderne. 
INDEX

Index géographique : Basse-Normandie, Manche (50), Saint-Lô

Index chronologique : Moyen Âge, Temps Modernes

operation Diagnostic (EV)

Mots-clés : fossé, mur

\section{AUTEUR}

LUDOVIC LE GAILLARD

Inrap 